\title{
Medicolegal
}

\section{Dr Gee goes to the House of Lords}

\author{
CLARE DYER
}

Dr Sidney Gee has kept the courts humming and the lawyers busy since 1983, when he issued a libel writ against the BBC in what eventually turned into the most expensive libel action in English legal history. Last week the highest court in the land, the House of Lords, reserved judgment on his challenge to charges by the General Medical Council of serious professional misconduct over his treatment of eight obese patients. The law lords are expected to rule within four to six weeks on whether the charges can go ahead as formulated and whether the Council will have to go through further preliminary steps before the inquiry can proceed.

\section{The story so far}

Dr Gee, a general practitioner in private practice with a special interest in obesity, sued the BBC and two doctors over criticisms of his treatment of a patient, Elizabeth Day, broadcast on Esther Rantzen's That's Life programme. After 92 days in court, still not at the halfway point, the action was settled in April 1985, with the BBC and the doctors agreeing to pay a total of $£ 100000$ in damages plus costs of around half a million pounds. After the collapse of the BBC case libel actions against the News of the World and the Daily Express over allegations about the treatment of Mrs Day and other patients were settled out of court with the payment of substantial damages and costs.

In April 1984, before the trial of the libel action began, Dr Gee was notified by the General Medical Council that it had received complaints and information from four patients, including complaints sworn by Mrs. Day and by her general practitioner, Dr Clemency Mitchell, one of the two doctors sued for libel. In May he was told that the preliminary proceedings committee, the committee that initially considers and filters complaints, had decided that he should be charged and that an inquiry by the professional conduct committee should go ahead. In June he was told what the charge was and was given particulars of the patientsnow not four, but eight-who were the subject matter of the charge.

He was charged with abusing his professional position as a medical practitioner by supplying, in return for fees, quantities of drugs, including dexamphetamine sulphate and thyroid extract, repeatedly over extensive periods (a) without first adequately examining the patients or seeking adequate information as to their medical history; $(b)$ without first consulting the patients' general practitioners about the proposed treatment or notifying those general practitioners about the details of any drugs supplied and the dosages prescribed after treatment had first started; $(c)$ without making adequate inquiries on each occasion about the effect of this treatment on the patients' health; and $(d)$ without offering

London NW1

CLARE DYER, BA, BLS, légal correspondent appropriate advice when a patient reported the harmful effects of the drugs supplied.

In July 1984, having had his request to the president of the General Medical Council for an adjournment of the inquiry turned down, he successfully applied to the High Court for judicial review of the president's decision. The inquiry was adjourned until after the disposal of the libel action. Dr Gee also objected to the way the charge was formulated. He argued that he would be prejudiced because the charge was "duplicitous"-in other words it rolled all the allegations up into one charge instead of splitting off the allegations into separate charges for each patient. He also argued that the professional conduct committee could not consider allegations relating to the extra four patients (the "group B" patients), whose names had been added after the complaints about the first four patients (the "group A" patients) had gone through the preliminary proceedings committee; if these were to be considered by the professional conduct committee they would first have to go through the preliminary proceedings committee's filter procedure. He asked the president of the General Medical Council to order the charge to be amended, sought assurances that the professional conduct committee would not begin to consider the charges relating to the group B patients, and asked for further particulars of the charges against him. All of these requests were refused, so he went back to the High Court in October 1985 to seek judicial review again. Mr Justice Mann ruled in his favour on all the points.

The General Medical Council appealed to the Court of Appeal, which in May 1986, by a majority of two to one, gave judgment in favour of the council. So far, therefore, two judges have come down in Dr Gee's favour, and two in favour of the General Medical Council. Last week five law lords finished hearing Dr Gee's appeal.

The issues that the law lords have been asked to rule on are: Is the charge duplicitous? If so, does it offend against any rule of law or natural justice? Does it comply with the requirements for a charge laid down in the General Medical Council's rules? Can the professional conduct committee properly begin to consider the charge? Is the professional conduct committee's inquiry limited in scope by the material available to the preliminary proceedings committee and if so how? Can the professional conduct committee consider evidence on allegations that were not brought before the preliminary proceedings committee but that relate to matters which were?

\section{Evidence in the House}

The Hon Michael Beloff QC, leading counsel for Dr Gee, submitted that the use of a rolled up charge would either deprive his client of rights granted by the rules or impair his exercise of those rights-the rights to have a finding of not guilty recorded on each particular charge, to submit no case to answer on any particular charge, to have recorded separate findings on each particular charge, and to have recorded a finding of not guilty if no evidence were adduced on any particular charge. He also argued that under a rolled up charge all the allegations of misconduct would be presented indiscriminately to the professional conduct committee; 
which; as a body of non-lawyers, would be unable to differentiate between the evidence in respect of each separate allegation. He added that the use of a duplicitous charge would give rise to uncertainty about which allegations had been found to be proved and hinder the presentation of an appeal before the Privy Council, particularly as it was not the practice of the professional conduct committee to give reasons for their decisions or to state in any detail the facts that had been proved. Mr Beloff also argued that under the General Medical Council's rules the professional conduct committee had no jurisdiction to inquire into allegations other than those that were referred to it by the preliminary proceedings committee concerning the group A patients unless and until those other matters were properly referred to it by the preliminary proceedings committee.

For the General Medical Council Mr Vivian Robinson QC submitted that the charge was not duplicitous. What was being alleged was a course of conduct that amounted to serious professional misconduct. The essence of the complaint lay in the phrase "abused your position as a medical practitioner"; on any reasonable construction this was a complaint about a course of conduct. $\mathrm{He}$ argued that even if the charge were duplicitous it was not bad for duplicity because Dr Gee was not prejudiced. The committee took great care to spell out exactly what facts they had found to be proved so that the practitioner's representative knew precisely on which proved facts he had to address the committee. On the addition of the four patients who had not been through the filter of the preliminary proceedings committee $\mathrm{Mr}$ Robinson argued that there was already a referred course of conduct to which this additional material was directly relevant. It was inconceivable that, having referred a case supported by four patients on this subject matter, the committee would take a different line with four different patients.

Mr Robinson acknowledged that the General Medical Council could have split the charge into eight charges. The reason for it not doing so and the reason for it now finding itself in the House of Lords was that the council thought that it would be totally wrong that it should be shackled in this way. It was in the public interest that the committee should be able to look compendiously at a doctor's conduct.

\section{Previous cases}

Practitioners found guilty of serious professional misconduct often exercise their right of appeal to the Privy Council (the law lords wearing another hat) against the findings, but this is the first attempt to mount a pre-inquiry court challenge to the charges themselves. In New Zealand a similar challenge on the point of duplicity was recently rejected by the full Court of Appeal; in that case the court approved the rolling up of four quite different types of alleged misbehaviour in an omnibus charge. In Dr Gee's case, by contrast, the allegations are of similar conduct in relation to several patients. In this country the duplicity point was an issue in an appeal to the Privy Council in Peatfield $v$ General Medical Council, a case in which the allegations were very similar to those against Dr Gee. The Privy Council, dismissing the doctor's appeal, took the view that the charge could be fairly read as alleging a course of conduct and that it was this course of conduct that amounted to serious professional misconduct.

\section{Medicine and the Media}

$W^{t}$ E ARE publishing the following few paragraphs as an example of how difficult it can be for journalists to get to the bottom of an issue. Two weeks ago we published a piece by fane Dawson, technical editor of the "British Heart fournal," in which she criticised the claims made by Express Dairy about its calcium supplemented skimmed milk product Vital (28 February, p 565). Afterwards she noticed that the advertisements for Vital had been much toned down and wrote the piece below.

The onward rush of the calcium bandwagon may have slowed a little. The latest in the series of Express Dairy advertisements for their newly launched calcium supplemented skimmed milk, called Vital, is more circumspect than forerunners that started to appear last month. These earlier advertisements, which were directed at women, claimed that an increased intake of calcium would "help to insure against the risk of osteoporosis," and suggested that health and figure conscious women were increasing their risk of broken and deformed bones by cutting their intake of milk. Subsequent criticism in the medical and scientific press that calcium supplementation, unlike hormone replacement treatment, was not effective against osteoporosis may have been noted by Express Dairy and its advertising agency.

The latest Vital advertisement, spotted in the Daily Mail on 2 March, is unexceptionable, merely giving a picture of the carton and describing its contents-"With extra calcium. Without the fat." This approach does away with the requirement for the footnote shown on earlier, more doom laden advertisements ... "If you are concerned about osteoporosis and your calcium intake, please consult your doctor." But for many women who have already seen and noted the earlier newspaper advertisements the seeds of concern will already have been sown.

Optimism that this is a new tack adopted as a responsible reaction to informed criticism is slightly dented by the appearance of one of the earlier advertisements in Woman magazine (28 February). Will it be replaced by a new style advertisement in later issues?

Ms Dawson then noticed the following sentence in of all unlikely publications "Ms London": "The way the government sees it is that claims that a food can help prevent or cure illness cannot be allowed unless the food has been given a product licence under the Medicines At..'. We asked her to chase up this interesting idea, and before leaving for the American College of Cardiology meeting in New Orleans she left the following memo.

"I have been ringing round to get some background to the change of tack on the advertising of Vital.

The message from Dr John Griffin [medical director of the Association of the British Pharmaceutical Industry and former head of the medicines division at the Department of Health and Social Security] seemed to be that you can't make medicinal claims for food products without falling foul of the Medicines Act.

I also 'phoned David Price at the DHSS. He said Jane Mayhew would 'phone back to discuss-she hasn't yet.

I 'phoned Express Dairy to ask why they had changed their advertising (Mr Viv Rudd). I was referred to their advertising agents (Mill S Frazer). Jeff Jackman was very chary. They were, he said, "addressing other possible creative solutions and copy options." He did concede that the change could be a reflection of the current climate. And then he referred me to the National Dairy Council, where Dr Judy Buttriss said that the NDC couldn't comment on the advertising of individual products by companies. The NDC is only concerned with generic advertising, she said.

I then 'phoned Viv Rudd at Express again. I asked if they had had many complaints about their earlier ads. He said that there had been "comments" and suggested that I. should speak to Roger Andrew, marketing manager. Mr Andrew was in a meeting, 